\title{
High-Temperature Interaction Between Molten AISr10 Alloy and Glass-Like Carbon Substrate
}

\author{
A. Siewiorek, N. Sobczak, J. Sobczak, A. Kudyba, R. Kozera, and A. Boczkowska
}

(Submitted January 2, 2016; in revised form February 29, 2016; published online March 17, 2016)

\begin{abstract}
Wettability of glass-like carbon substrate $\left(\mathrm{C}_{\mathrm{glc}}\right)$ by molten $\mathrm{Al}-10 \mathrm{wt}$ \% $\mathrm{Sr}$ alloy (AISr10) has been examined by a sessile drop method at $700-800{ }^{\circ} \mathrm{C}$ for 120 min under vacuum. Non-contact heating to the test temperature combined with the removal of oxide film from the alloy drop was done using capillary purification procedure by squeezing the liquid alloy from a capillary. The influence of the type of capillary on wetting behavior of $\mathrm{AlSr10} / \mathrm{C}_{\text {glc }}$ couples was noticed. Molten AISr10 alloy does not wet $\mathrm{C}_{\text {glc }}$ at about $700{ }^{\circ} \mathrm{C}$ forming the contact angles of $111^{\circ}$ with graphite capillary and $141^{\circ}$ with alumina capillary. At $800{ }^{\circ} \mathrm{C}$ with alumina capillary, non-wetting-to-wetting transition takes place resulting in a final contact angle of $70^{\circ}$. After testing at $800{ }^{\circ} \mathrm{C}$, the $\mathrm{AISr} 10 / \mathrm{C}_{\mathrm{glc}}$ interface was revealed at the test temperature directly in the vacuum chamber by the drop suction procedure. Structural characterization of the interfaces by scanning and transmission electron microscopy combined with energy-dispersive $x$-ray spectroscopy and by scanning probe microscopy combined with Auger electron spectrometry did not show any new phases formed with Sr. It suggests that the dominant role in wettability improvement by alloying Al with 10 wt.\% $\mathrm{Sr}$ was related with significant lowering of the surface tension of liquid metal and adsorption of $\mathrm{Sr}$ at the interface.
\end{abstract}

Keywords Al/C, Al-Sr, drop suction, interfaces, sessile drop, wetting

\section{Introduction}

Information about factors affecting the interaction between liquid aluminum and aluminum alloys with carbon is of practical importance for the development of light-weight aluminum matrix composites of Al-C type reinforced with different carbon materials $(\mathrm{C}$ - fibers, graphite or diamond particles, carbon nanotubes) using different liquid-assisted processes. It is widely recognized (Ref 1-10) that at industrially important temperatures $\left(T<900{ }^{\circ} \mathrm{C}\right)$ and short-time contact, liquid $\mathrm{Al}$ and most $\mathrm{Al}$ alloys do not wet carbon materials, independently on their allotropic form. At higher temperature and longer contact time, wetting in the $\mathrm{Al} / \mathrm{C}$ system is accompanied with the formation of undesirable carbide

This article is an invited submission to JMEP selected from presentations at the Symposium "Wetting and High-Temperature Capillarity," belonging to the Topic "Joining and Interfaces" at the European Congress and Exhibition on Advanced Materials and Processes (EUROMAT 2015), held on September 20-24, 2015, in Warsaw, Poland, and has been expanded from the original presentation. Electronic supplementary material The online version of this article (doi:10.1007/s11665-016-2003-x) contains supplementary material, which is available to authorized users.

A. Siewiorek, J. Sobczak, and A. Kudyba, Foundry Research Institute, 73 Zakopianska Street, 30-418 Krakow, Poland; N. Sobczak, Foundry Research Institute, 73 Zakopianska Street, 30-418 Krakow, Poland, and Motor Transport Institute, 80 Jagiellonska Street, 03-301 Warsaw, Poland; R. Kozera and A. Boczkowska, Warsaw Technical University, 141 Woloska Street, 02-507 Warsaw, Poland. Contact e-mail: aleksandra.siewiorek@gmail.com.
$\mathrm{Al}_{4} \mathrm{C}_{3}$, responsible for low corrosion resistance and brittleness of composite material. Improvement in low temperature wettability of the $\mathrm{Al} / \mathrm{C}$ system can be achieved either by alloying Al with reactive additions such as Ti (Ref 7, 10, 11) and $\mathrm{Si}$ (Ref 9,11) or by covering carbon surfaces with technological coating either metallic [e.g., $\mathrm{Cu}, \mathrm{Ni}(\operatorname{Ref} 11,12)$ ] or metal-like ceramics [e.g., $\mathrm{TiB}_{2}$ (Ref 13)]. Addition of $\mathrm{Ti}$ improves physico-chemical compatibility in the $\mathrm{Al} / \mathrm{C}$ system because of the formation of TiC instead of $\mathrm{Al}_{4} \mathrm{C}_{3}$ (Ref 7, 10, 14-16). However, it was found that introduction of reactive alloying elements that form new carbide phases at the interface instead of undesirable $\mathrm{Al}_{4} \mathrm{C}_{3}$ does not guarantee its complete elimination. Particularly, it takes place in long-time processes because the kinetic factors play a dominant role, as discussed in (Ref 16).

Baumli et al. (Ref 17) reported the effect of molten salts (fluxes) on the wettability of graphite and glass-like carbon by liquid $\mathrm{Al}$ using $\mathrm{MCl}-\mathrm{K}_{2} \mathrm{TiF}_{6}$ salt mixtures, where $\mathrm{MCl}$ was $\mathrm{LiCl}, \mathrm{NaCl}-\mathrm{KCl}$, or $\mathrm{CsCl}$. They found the conditions of perfect wetting as a function of flux, temperature, flux to aluminum weight ratio, specific surface area of $\mathrm{Al}$, and specific surface area of carbon substrate. The new concept proposed by Baumli et al. (Ref 17) is based on application of molten salts both for the formation of $\mathrm{TiC}$ at the interface through interaction between liquid $\mathrm{Al}$ and $\mathrm{K}_{2} \mathrm{TiF}_{6}$ at $700{ }^{\circ} \mathrm{C}$ and for perfect wetting of TiC by liquid Al. Since at that temperature liquid $\mathrm{Al}$ does not wet $\mathrm{TiC}$ in a gas atmosphere, one may suggest that the environment of molten flux selected by Baumli et al. is a key factor of beneficial change of interfacial energy in the system.

To our best knowledge, there are no systematic studies in the literature on application of another approach to improve low temperature wetting in the $\mathrm{Al} /$ ceramic systems by alloying of a metal with surface active additions allowing significant decrease in surface tension of a molten metal. Literature data on the surface tension of pure $\mathrm{Al}$ are very scattered due to high sensitivity of $\mathrm{Al}$ to oxidation, and even for the temperatures close to melting point 
of Al, they are in the range of about 820-1100 mN/m (Ref 18-26). Among alloying elements used in commercial Al alloys such additions as $\mathrm{Li}, \mathrm{Bi}, \mathrm{Pb}, \mathrm{Mg}, \mathrm{Sb}, \mathrm{Ca}, \mathrm{Sn}$, and $\mathrm{Sr}$ are known to reduce the surface tension of $\mathrm{Al}$, while $\mathrm{Ge}, \mathrm{Zn}, \mathrm{Ag}, \mathrm{Fe}, \mathrm{Mn}, \mathrm{Ni}$, and $\mathrm{Cu}$ increase the surface tension (Ref 22, 23, 27-29). Nevertheless, the effect of alloying elements on interaction in different $\mathrm{Al} /$ ceramic systems has been discussed in several publications [e.g., (Ref 18, 19, 30-32)]. By applying the sessile drop (SD) method at $750{ }^{\circ} \mathrm{C}$, Candan (Ref 18) made the direct measurements of the contact angles $(\theta)$ formed by different $\mathrm{Al}$ alloys on $\mathrm{SiC}$ substrates and found that the addition of $1.4 \mathrm{wt} . \%$ $\mathrm{Pb}$ to $\mathrm{Al}$ causes slight decrease of $\theta\left(118^{\circ}\right)$, compared to pure $\mathrm{Al}$ $\left(123^{\circ}\right)$; alloying Al with 3.4 wt. $\% \mathrm{Mg}$ or 0.8 wt. $\%$ Ca contributes to better wettability improvement $\left(113^{\circ}\right.$ and $105^{\circ}$, respectively) and only $\mathrm{Al}-8.6 \mathrm{Mg}$ and $\mathrm{Al}-13.9 \mathrm{Mg}$ alloys wet $\mathrm{SiC}\left(65^{\circ}\right.$ and $59^{\circ}$, respectively). Candan (Ref 18) suggested that the smallest effect on wetting properties observed for $\mathrm{Al}-1.4 \mathrm{~Pb}$ alloy is related with the decrease in surface tension of liquid metal, while the strongest effect noted for $\mathrm{Al}-8.6 \mathrm{Mg}$ and $\mathrm{Al}-13.9 \mathrm{Mg}$ alloys is dominated by interfacial reaction and the formation of $\mathrm{Mg}_{2} \mathrm{Si}$. On the contrary, Alonso et al. (Ref 19) reported that the addition of only $1 \mathrm{wt} . \%$ $\mathrm{Pb}$ to aluminum causes the $75 \%$ reduction in the threshold pressure needed for infiltration of different ceramic particulates ( $\mathrm{SiC}, \mathrm{TiC}, \mathrm{Al}_{2} \mathrm{O}_{3}$ ). Alonso et al. explained this effect by $23 \%$ decrease in the surface tension of liquid metal from $863 \mathrm{mN} / \mathrm{m}$ for pure aluminum to $662 \mathrm{mN} / \mathrm{m}$ for Al-1Pb alloy. However, due to environmental reasons as well as due to high density of $\mathrm{Pb}$, alloying $\mathrm{Al}$ with $\mathrm{Pb}$ has no practical interest in the production of light-weight Al-matrix composites.

Bahraini et al. (Ref 30) reported no positive effect of silicon additions to aluminum on infiltration of diamond particle preforms with Al-Si alloys containing 7, 10, and 13\% Si. Using the results of infiltration tests, they calculated the contact angles and found that their values are relatively independent on the $\mathrm{Si}$ content $\left(134^{\circ}\right.$ and $141^{\circ}$ for pure $\mathrm{Al}$ and Al-13Si alloy, respectively). By applying similar methodological approach, allowing indirect estimation of contact angles from infiltration tests, Molina et al. acquired high contact angle of $139^{\circ}$ also for graphite with similar alloy containing $12 \% \mathrm{Si}$ (Ref 31$)$. These results are in agreement with the study of Rodriguez-Guerrero et al. (Ref 32) on pressure infiltration of graphite particle preforms with pure $\mathrm{Al}$ and $\mathrm{Al}$ alloys. Rodriguez-Guerrero et al. found that independently on the size of graphite particles used $(15.1-64.0 \mu \mathrm{m})$ there was no positive effect of $12 \mathrm{wt} . \% \mathrm{Si}$ addition on infiltration since the threshold pressure with pure $\mathrm{Al}$ is lower than that with Al-12Si alloy (1128-201 kPa and 1439$283 \mathrm{kPa}$, respectively). Although alloying of Al-12Si with 1 wt. $\% \mathrm{Cu}$ resulted in $3 \%$ decrease of the surface tension of liquid alloy from $855 \mathrm{mN} / \mathrm{m}$ to $830 \mathrm{mN} / \mathrm{m}$, its effect on infiltration improvement was negligible. Almost no influence on the surface tension of Al-12Si alloy was observed with 0.5 1.5 wt. $\%$ Ti additions (858-855 mN/m, respectively). Consequently, higher threshold pressure needed for infiltration of the same preforms was recorded. On the contrary, significant reduction in the threshold pressure took place after addition of 4 wt.\% Mg, i.e., from $1439 \mathrm{kPa}$ (Al-12Si alloy) to $552 \mathrm{kPa}$ (Al$12 \mathrm{Si}-4 \mathrm{Mg}$ alloy). Rodriguez-Guerrero et al. explained these results by $19 \%$ reduction of the surface tension of liquid metal from $855 \mathrm{mN} / \mathrm{m}$ (Al-12Si alloy) up to a value of $694 \mathrm{mN} / \mathrm{m}$ (Al-12Si-4Mg alloy).

Compared to the above-mentioned alloying additions, the strongest effect on the surface tension of liquid Al alloys was experimentally evidenced for $\mathrm{Sr}$ and $\mathrm{Na}$. By a SD method at
$685{ }^{\circ} \mathrm{C}$, Emadi et al. (Ref 20) demonstrated that very small additions of 0.01 wt. $\% \mathrm{Sr}$ or 0.005 wt. $\% \mathrm{Na}$ to commercial A356 alloy (Al-7.3wt.\%Si-0.4wt.\%Mg) decreased its surface tension at $685{ }^{\circ} \mathrm{C}$ from $790 \mathrm{mN} / \mathrm{m}$ by about $19 \%$ and $10 \%(640$ and $715 \mathrm{mN} / \mathrm{m}$ ), respectively. In addition, $0.01 \mathrm{wt} \% \mathrm{Sr}$ reduces surface tension of A356 alloy more (from 790 to $640 \mathrm{mN} / \mathrm{m}$ ) than does $10 \mathrm{wt} . \% \mathrm{Sr}$ in pure Al (where surface tension was $685 \mathrm{mN} / \mathrm{m}$ ), probably due to the effect of alloying elements in the A356 alloy (Ref 20). For the same A356 alloy, similar effect of $\mathrm{Sr}$ was reported also by Anson et al. at $630{ }^{\circ} \mathrm{C}$ (Ref 21) showing the reduction of surface tension from 889 to $844 \mathrm{mN} / \mathrm{m}$ when 0.015 wt. $\% \mathrm{Sr}$ was added. Following the report by $\mathrm{G}$. Lang for pure $\mathrm{Al}$, the effect of $\mathrm{Sr}$ is less pronounced since addition of $0.01 \mathrm{wt} . \% \mathrm{Sr}$ reduces the surface tension of pure aluminum at $700{ }^{\circ} \mathrm{C}$ by about $2 \%(\operatorname{Ref} 22,23)$. Despite the fact that these results are in agreement with those obtained by Emadi et al. (Ref 20) for Al alloy containing $10 \mathrm{wt} \% \mathrm{Sr}$ at $685{ }^{\circ} \mathrm{C}$, we suggest that the value of surface tension given by Emadi et al. for the Al-10Sr alloy is overestimated and corresponds to much lower $\mathrm{Sr}$ content in molten Al-Sr alloy. At a temperature of $685^{\circ} \mathrm{C}$, the alloy is in semi-liquid state and a significant amount of $\mathrm{Sr}$ is accumulated in the intermetallic precipitates $\mathrm{Al}_{4} \mathrm{Sr}$, while the liquid has much less Sr, compared to nominal composition of the alloy. Taking into account that the surface tension of liquid $\mathrm{Sr}$ $(296 \mathrm{mN} / \mathrm{m})$ is almost three times lower than the surface tension of liquid $\mathrm{Al}$, it was assumed that alloying $\mathrm{Al}$ with higher amount of $\mathrm{Sr}$, compared to that reported in the literature, should significantly decrease its surface tension. Moreover, strontium with its density of $2.6 \mathrm{~g} / \mathrm{cm}^{3}$, comparable to that of pure $\mathrm{Al}\left(2.7 \mathrm{~g} / \mathrm{cm}^{3}\right)$, belongs to a group of alloying elements that are attractive for light-weight Al-matrix composites.

This study is focused on examination of the influence of alloying Al with high amount of strontium (10 wt.\%) as well as temperature on the interaction between liquid $\mathrm{Al}$ alloy and glass-like carbon substrates $\left(\mathrm{C}_{\mathrm{glc}}\right)$ and their effects on wetting behavior, reactivity, and interfaces in the $\mathrm{Al} / \mathrm{C}_{\text {glc }}$ system.

\section{Materials and Experimental Procedure}

Wettability and reactivity tests of molten Al-10 wt.\% Sr alloy (A1Sr10) in contact with glass-like carbon substrates $\left(\mathrm{C}_{\mathrm{glc}}\right)$ were performed by a $\mathrm{SD}$ method allowing the direct measurements of the contact angle $\theta$ from the image of metal drop deposited on the substrate (Ref 33,34$)$. The $C_{\text {glc }}$ substrates (MINERAL Co.) were in the form of a coupon of $10 \mathrm{~mm}$ length, $10 \mathrm{~mm}$ width, and $3 \mathrm{~mm}$ thickness and with roughness below $50 \mathrm{~nm}$. Directly before high-temperature wettability tests, the metal and substrate samples were ultrasonically cleaned in isopropanol. In order to avoid the effect of gasification, the $\mathrm{C}_{\mathrm{glc}}$ substrates were preheated in dynamic vacuum at $1000{ }^{\circ} \mathrm{C}$ for $30 \mathrm{~min}$. The $\mathrm{SD}$ tests were performed using experimental complex for investigation of high-temperature capillarity phenomena ( Ref 35 ). Experimental conditions were temperature 700,710 , and $800^{\circ} \mathrm{C}$, vacuum $10^{-7}-10^{-6}$ mbar, and $120 \mathrm{~min}$ of contact time at the test temperature. The liquid drops were produced using capillary purification (cp) procedure, allowing in situ removal of native oxide film from the $\mathrm{Al}$ drop directly in vacuum chamber in order to improve the reliability of contact angle measurements with liquid Al (Ref 36). For this reason, a metal sample and a substrate were heated 
I.
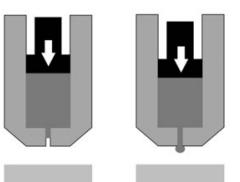

(a) capillary purification (cp)
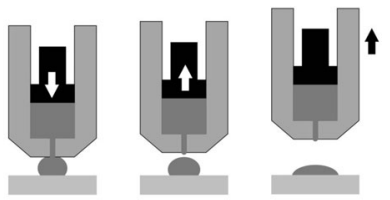

政

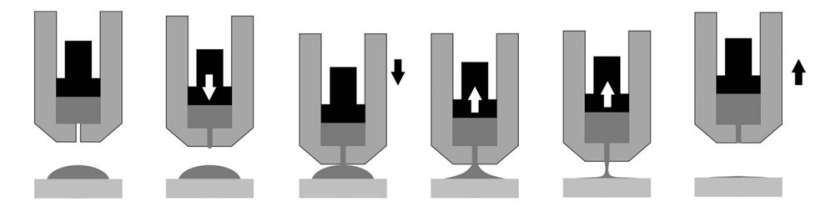

(b) drop suction (ds)

Fig. 1 Procedures used in wettability tests by a sessile drop (SD) method for opening the interface at high processing temperature: (a) capillary purification (cp) and (b) drop suction (ds) (Ref 35)

separately to the test temperature and a metal drop was produced by squeezing of a liquid metal through a hole in a graphite capillary $\left(700{ }^{\circ} \mathrm{C}\right)$ or an alumina capillary $(710$ and $800{ }^{\circ} \mathrm{C}$ ) and finally deposited on the $\mathrm{C}_{\mathrm{glc}}$ substrate.

For the test performed at $800{ }^{\circ} \mathrm{C}$, after 120 -min contact the drop was sucked from the substrate surface into a ceramic capillary in order to open the drop/substrate interface using drop suction (ds) procedure (Ref 35) (Fig. 1).

During the wettability tests, high-resolution images $(1152 \times 864$ pixels $)$ of the $\mathrm{AlSr} 10 / \mathrm{C}_{\text {glc }}$ couple were recorded by high-resolution digital camera with a rate of $26 \mathrm{fps}$ (frames per second) during dropping. After dropping, the registration was changed to $10 \mathrm{fps}$, while during sucking and cooling it was 1 fps. The collected images were used for computed image analysis allowing an estimation of the contact angle values by means of ASTRA software (Ref 37).

The observations of the solidified drop/substrate couples after wettability tests were performed by scanning electron microscopy (SEM) using Hitachi TM3000 device as well as Hitachi SU70 unit, both equipped with energy-dispersive x-ray spectroscopy (EDS) analyzers. Surface characterization of the residual drop and in situ exposed interface, formed due to interaction between the drop and the substrate, was made by auger electron spectrometry (AES) using Microlab 350 device. Additionally, scanning probe microscopy characterization combined with Raman spectroscopy of the $\mathrm{C}_{\text {glc }}$ surface affected by liquid alloy was performed using NTEGRA SPECTRA system of NT-MDT Europe BV. The reaction zone of cross-sectioned couples was analyzed by high-resolution scanning transmission electron microscopy (STEM) using Hitachi S5500 unit and Jeol 1200 TEM. For the TEM observations, the samples were prepared with Focused Ion Beam (FIB) using a FB2100 Hitachi unit.

\section{Results and Discussion}

Figure 2 shows the wettability kinetics of liquid AlSr10 alloy on the $\mathrm{C}_{\mathrm{glc}}$ substrates at different temperatures for 120min tests. The AlSr10 alloy does not wet glass-like carbon at 700 and $710^{\circ} \mathrm{C}$, forming high contact angles $\theta>90^{\circ}$. At lower temperature of $700{ }^{\circ} \mathrm{C}$, the contact angle value of $111^{\circ}$ does not

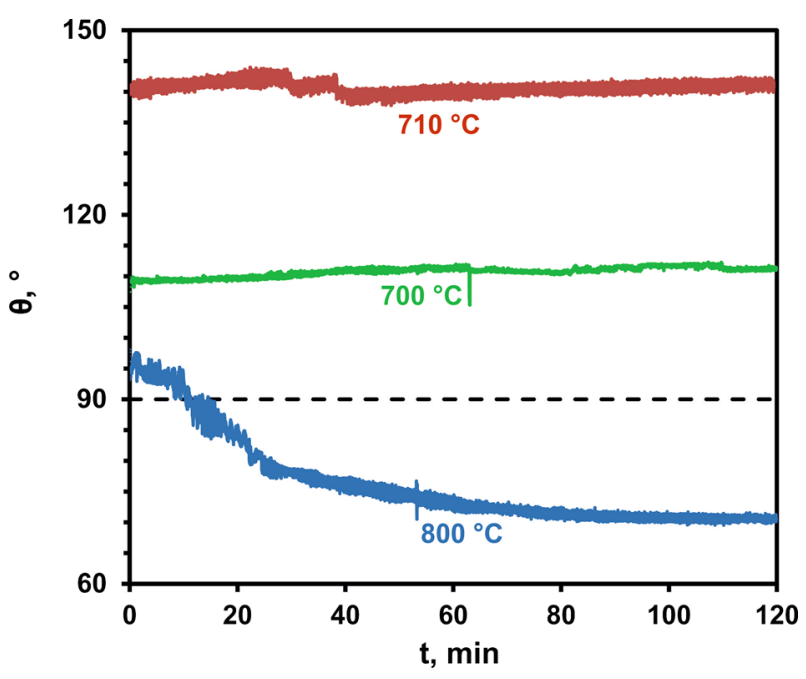

Fig. 2 Effect of temperature and type of capillary on wettability kinetics of liquid $\mathrm{AlSr} 10$ alloy on $\mathrm{C}_{\mathrm{glc}}: 700{ }^{\circ} \mathrm{C}$-graphite capillary; 710 and $800{ }^{\circ} \mathrm{C}$-alumina capillary

change with time, while at $710^{\circ} \mathrm{C}$, it slightly decreases after 40 -min interaction to form the final angle $\theta_{\mathrm{f}}=141^{\circ}$. These two tests show large difference in contact angle values of $30^{\circ}$ despite of only $10{ }^{\circ} \mathrm{C}$ change in temperature and smaller value of contact angle recorded at lower temperature of $700{ }^{\circ} \mathrm{C}$, compared to that at higher temperature of $710{ }^{\circ} \mathrm{C}$. Such unusual $\theta-T$ relationship can be explained by usage of dissimilar capillaries, i.e., in the $700{ }^{\circ} \mathrm{C}$ test, it was made from graphite, while in the $710{ }^{\circ} \mathrm{C}$ test, it was made from alumina. As it has been evidenced in (Ref 34), in high-temperature SD tests performed under dynamic vacuum, the graphite capillary may play a role of a getter because residual oxygen in a vacuum chamber reacts with graphite to form $\mathrm{CO}_{2}$ that is evacuated from the chamber by working vacuum pump. Consequently, it leads to beneficial decrease in oxygen partial pressure in the chamber that in turn may contribute to better wetting properties of the $\mathrm{Al} /$ ceramic couples.

Increase in temperature up to $800{ }^{\circ} \mathrm{C}$ caused different wetting behavior of the $\mathrm{AlSr} 10 / \mathrm{C}_{\mathrm{glc}}$ couple as documented in Fig. 2 and 3. The images of Fig. 3 correspond to a few important stages of the SD test performed at $800^{\circ} \mathrm{C}$, i.e., the start of liquid metal dropping from the alumina capillary (Fig. 3a), disconnecting the drop from the capillary (Fig. 3b), the drop immediately after its deposition on the substrate (Fig. 3c), the drop/substrate couple during interaction at the test temperature (Fig. 3d-g), as well as the drop suction after the SD test (Fig. $3 \mathrm{i}$ and j). The corresponding movie of the whole test is given in SUPPLEMENT \#1.

At $800{ }^{\circ} \mathrm{C}$, the AlSr10 drop does not wet the $\mathrm{C}_{\text {glc }}$ substrate immediately after its squeezing from alumina capillary and deposition on the substrate $\left(\theta_{0}=95^{\circ}\right)$. The contact angle decreases with time showing non-wetting-to-wetting transition in 10th minute and finally stabilizes after about $80 \mathrm{~min}$ to form $\theta_{\mathrm{f}}=70^{\circ}$.

Comparison of the results of wettability tests obtained in this study to those reported in the literature for the $\mathrm{Al} / \mathrm{C}$ system (Ref 1-10) shows that alloying $\mathrm{Al}$ with $10 \mathrm{wt} . \% \mathrm{Sr}$ improves wetting, particularly at $800^{\circ} \mathrm{C}$. Under similar testing conditions (temperature, vacuum, glass-like carbon substrates) and using classical contact heating procedure, Nicholas et al. (Ref 1) 


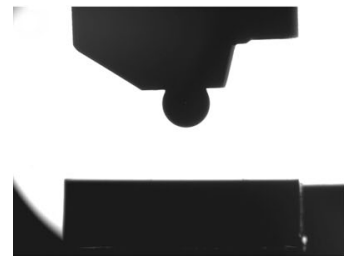

(a)

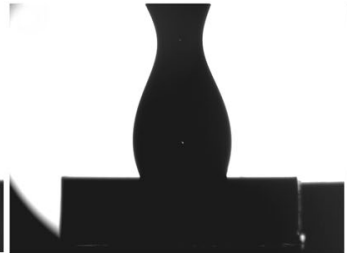

(b) (g)

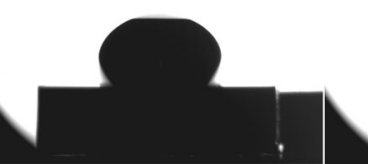

(c)

(d)

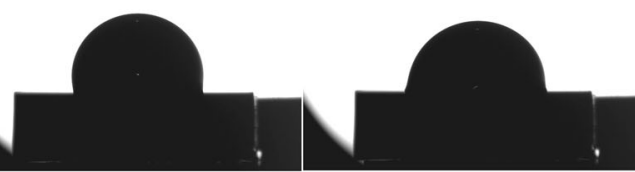

(e)

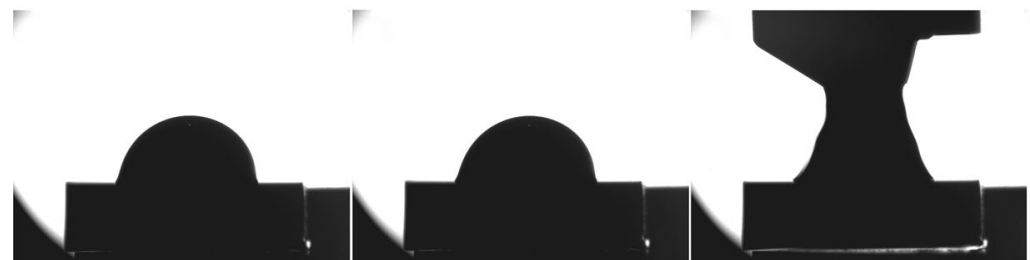

(f) (h)

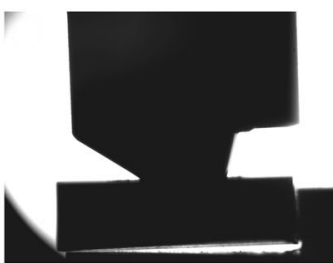

(i)

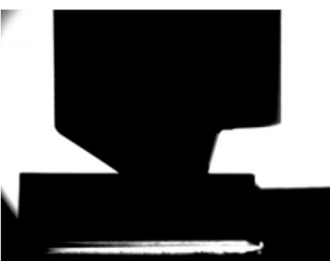

(j)

Fig. 3 Images taken from $\mathrm{SD} / \mathrm{cp}+\mathrm{ds}$ test for $\mathrm{AlSr} 10 / \mathrm{C}_{\mathrm{glc}}$ couple at $800{ }^{\circ} \mathrm{C}$ for 120 min recorded with the high-speed high-resolution camera showing the most representative moments of the test: (a) the start of dropping from alumina capillary; (b) disconnecting the drop from the capillary; (c) immediately after drop deposition; (d) test time $t=0 \mathrm{~min}$; (e) $t=30 \mathrm{~min}$; (f) $t=60 \mathrm{~min}$; (g) $t=90 \mathrm{~min}$; (h) first attempt of "simple" drop suction that caused the substrate lifting up; (i) drop suction made simultaneously with lowering the capillary; (j) end of drop suction accompanied by slight movement of the capillary to the right side of the substrate being fixed on the substrate support

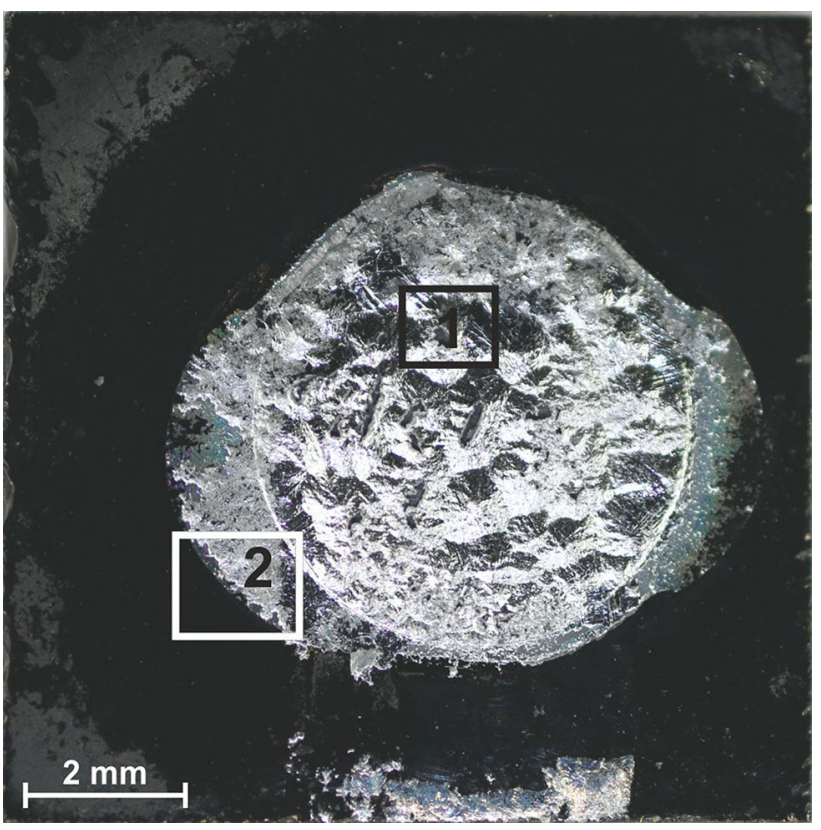

Fig. 4 Top-view of $\mathrm{AlSr} 10 / \mathrm{C}_{\text {glc }}$ couple after wettability test $\left(800{ }^{\circ} \mathrm{C}, \mathrm{SD} / \mathrm{cp}+\mathrm{ds}, 120 \mathrm{~min}\right)$ : 1 -region from which Raman spectroscopy was performed (Fig. 10); 2-area of SEM analysis shown in Fig. 5, 6, and 8

noted $\theta_{\mathrm{f}}=145^{\circ}$, while Eustathopoulos et al. (Ref 2) observed $\theta=125^{\circ}$ after 125 -min interaction. At comparable temperature of $820^{\circ} \mathrm{C}$ and with the same contact heating procedure, Kalogeropoulou et al. (Ref 5) obtained $\theta=128^{\circ}$ after $30 \mathrm{~min}$. However, during long-time contact of $300 \mathrm{~min}$ at that temperature, they observed continuous decrease in contact angle with time to the value of $\theta_{\mathrm{f}}=65^{\circ}$.

Landry et al. (Ref 6) demonstrated that scattering of literature data for contact angle values reported for the $\mathrm{Al} / \mathrm{C}$ system is related with the effect of native oxide film on $\mathrm{Al}$ drop preventing the establishment of a true drop/substrate contact. By applying two different testing procedures in the SD tests of
$\mathrm{Al} / \mathrm{C}_{\text {glc }}$ couples at $880{ }^{\circ} \mathrm{C}$, Landry et al. (Ref 6) obtained $\theta=74^{\circ}$ using contact heating procedure and $\theta=64^{\circ}$ with improved capillary purification technique, but in both cases for much longer contact time, compared to this study.

With the aim to explain the role of $\mathrm{Sr}$ in the wetting behavior of AlSr10 alloy on glass-like carbon substrate, the detailed characterization of the interface formed in the $\mathrm{AlSr} 10 / \mathrm{C}_{\mathrm{glc}}$ couple at $800{ }^{\circ} \mathrm{C}$ was performed. In order to avoid the effect of cooling history on the interface structure and chemistry, the attempt has been done to open the interface directly in vacuum chamber. For this purpose, immediately after testing at $800{ }^{\circ} \mathrm{C}$ for $120 \mathrm{~min}$ the drop suction procedure (Fig. 1b), allowing to remove the metal inside the capillary (Ref 35 ), was applied. However, as evidenced in SUPPLEMENT \#1 and Fig. $3 \mathrm{~h}$, this process was accompanied with movement of the substrate and its lifting up. Such behavior of the substrate during drop suction presents an experimental evidence of a strong adhesion established between the drop and the substrate and it has an agreement with good wetting of $\mathrm{C}_{\text {glc }}$ by liquid AlSr10 alloy observed in this study. Since under these circumstances, a complete removal of the drop by "simple" suction becomes impossible, a partial opening of the interface was achieved by simultaneous drop suction and lowering of the capillary (Fig. 3i) together with its slight movement to the right side, as shown in Fig. 3(j). Note that the position of the substrate was fixed using a special design of the substrate support (SUPPLEMENT \#1).

Figure 4 presents the top-view of AlSr $10 / \mathrm{C}_{\text {glc }}$ sample after wettability test at $800{ }^{\circ} \mathrm{C}$ and partial opening the interface directly in vacuum chamber. A few regions can be well distinguished as follows: (1) bright area 1 represents the residual drop and corresponds to the 1 st position of the drop during 120-min test; (2) area 2 is a region corresponding to the opened interface due to drop suction and movement; (3) wide black ring surrounding area 2 corresponds to the substrate surface affected by metal vapor; (4) bright area near the bottom substrate edge presents the trace of the alloy formed during manipulation with the drop that caused metal smearing along the substrate surface. 

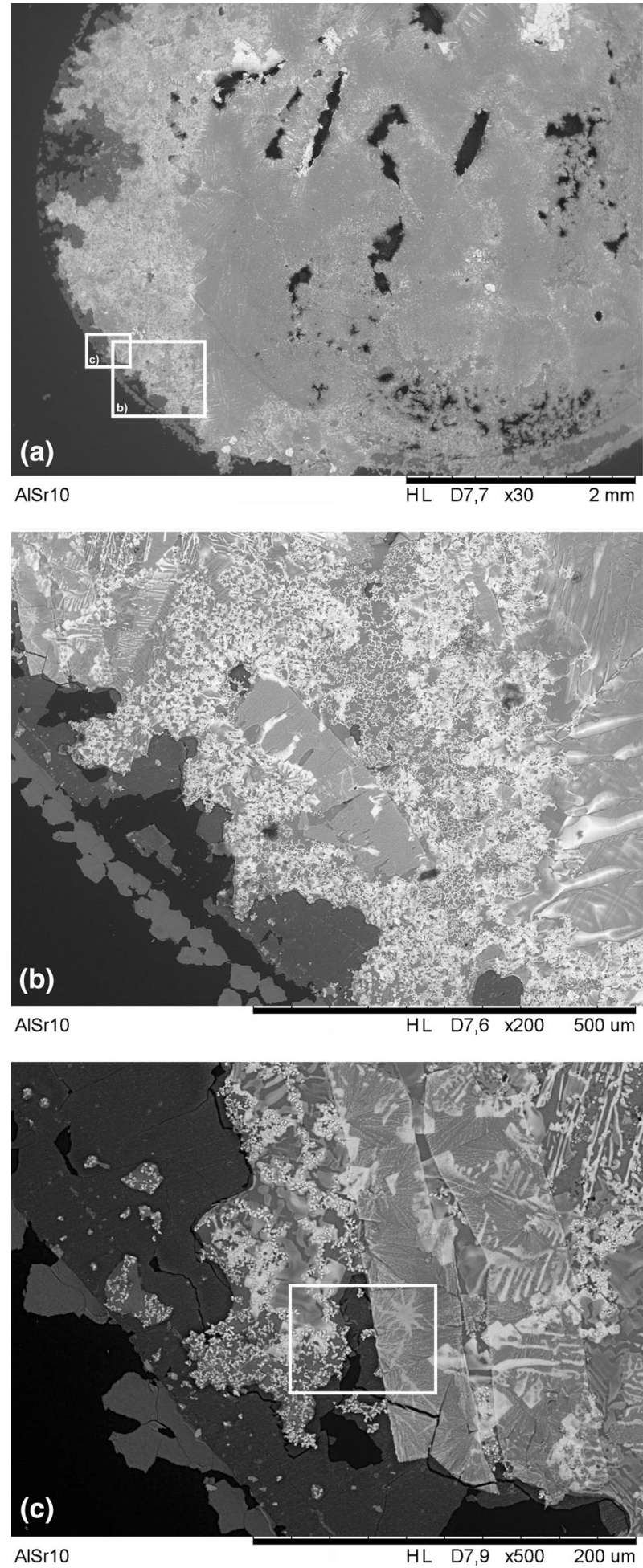

Fig. 5 SEM top-view images of $\mathrm{AlSr} 10 / \mathrm{C}_{\text {glc }}$ couple after wettability test at $800{ }^{\circ} \mathrm{C}(\mathrm{SD} / \mathrm{cp}+\mathrm{ds}, 120 \mathrm{~min})$ : (a) general view; (b, c) the outer area near the initial position of the triple line and opened drop/substrate interface; the rectangle marks the area of EDS analysis shown in Fig. 6

The detailed SEM observations of the area 2, marked in Fig. 4, show two regions of dissimilar structure and chemistry (Fig. 5a and b). The outer region corresponding to the exposed interface presents the interfacial layer. It is smooth and has

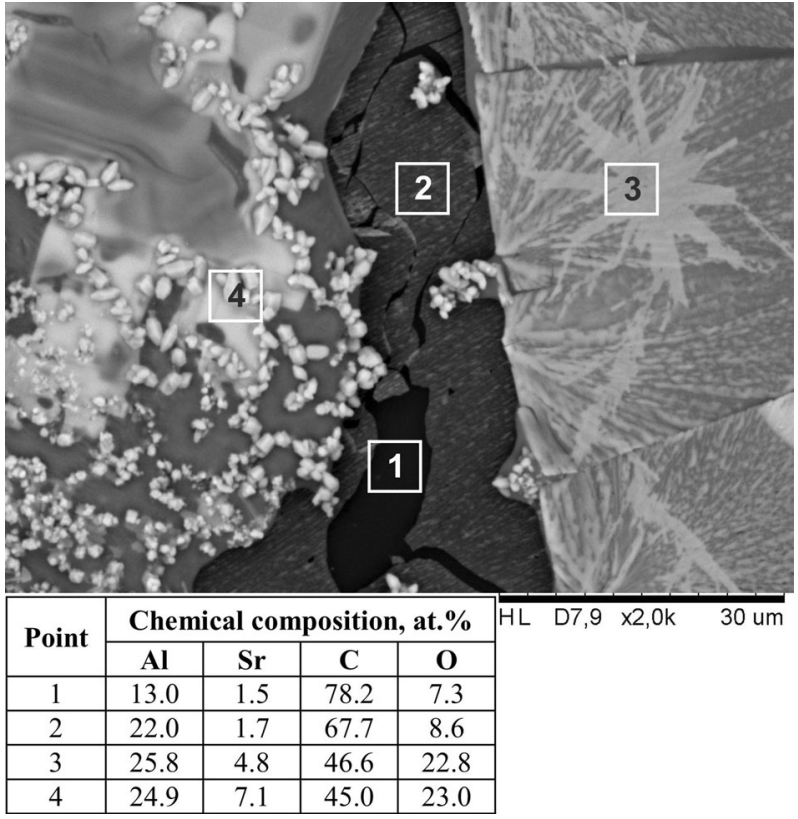

Fig. 6 Top-view SEM image of the residual drop resting on $\mathrm{C}_{\mathrm{glc}}$ substrate and opened drop/surface interface together with EDS analysis in marked area: 1 -opened interface with detached interfacial layer; 2-opened interface covered with interfacial layer; 3-drop surface being in contact with area 2 before drop suction and duplicating the topography of interfacial layer; 4-surface of residual drop covered with precipitates

"snowflakes" structure. This layer is discontinuous and occasionally detached from the substrate (Fig. 5c and d). The SEM/EDS analysis of the area marked in Fig. 5(d), corresponding to the partially exposed drop/substrate interface in the vicinity of the initial position of the triple line (Fig. 6), reveals that the interface is not homogeneous. It is composed of black area (1), corresponding to the substrate being less attacked by the liquid alloy, and dark gray area (2), corresponding to the reactively formed layer of high amount of $\mathrm{Al}$ and about 45 at.\% of carbon that matches the $\mathrm{Al}_{4} \mathrm{C}_{3}$ phase. This layer is cracked and occasionally it is detached thus revealing the substrate-side interface under the layer. The surface of the interfacial layer (area 2) has dashed-like topography. The same one is observed on the surface of the residual drop on the right side of Fig. 6 (area 3), thus suggesting that this part of the drop is covered with thin reaction product layer detached from the interface and transferred on the drop surface during its suction. It should be highlighted that the above phenomenon is common and takes place during drop suction of many metal/ceramic couples. Usually, we observe it when reactively formed precipitates or even fragments of interfacial layer are wettable by the liquid metal and do not form a strong bonding with the substrate. Additionally, the surface of residual drop is covered with numerous white precipitates immersed in the Al matrix and rich in $\mathrm{Sr}$ (area 4 in Fig. 6).

Further SEM observations under high magnifications evidenced two kinds of the characteristic structural features: (1) cuboidal precipitates of average $10 \mu \mathrm{m}$ length at the exposed drop/substrate interface with obviously visible, significant degradation due to cracking (area 1 in Fig. 7a-c); (2) regular crystals of average $2 \mu \mathrm{m}$ size on the drop surface in the vicinity of the opened interface (area 2 in Fig. $7 b$ and d). The EDS 


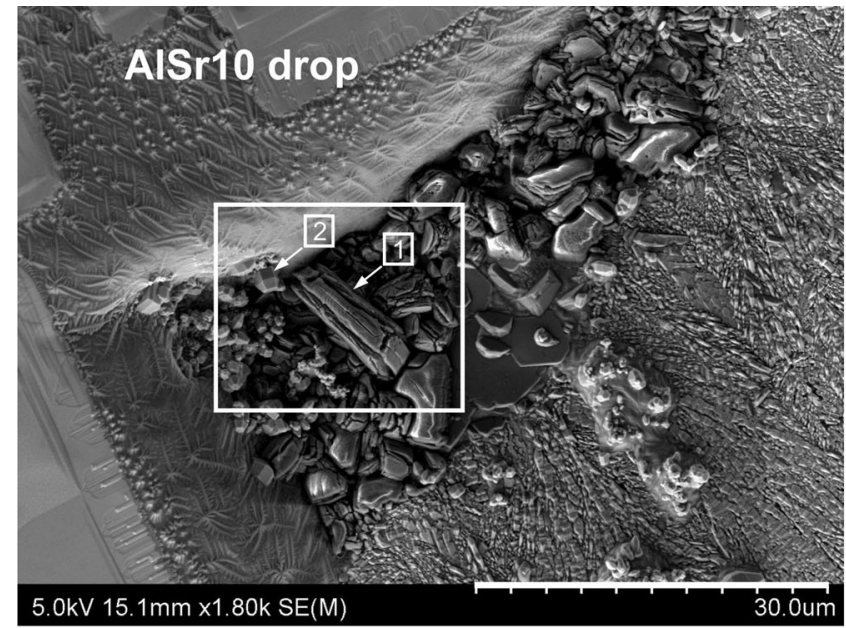

(a)

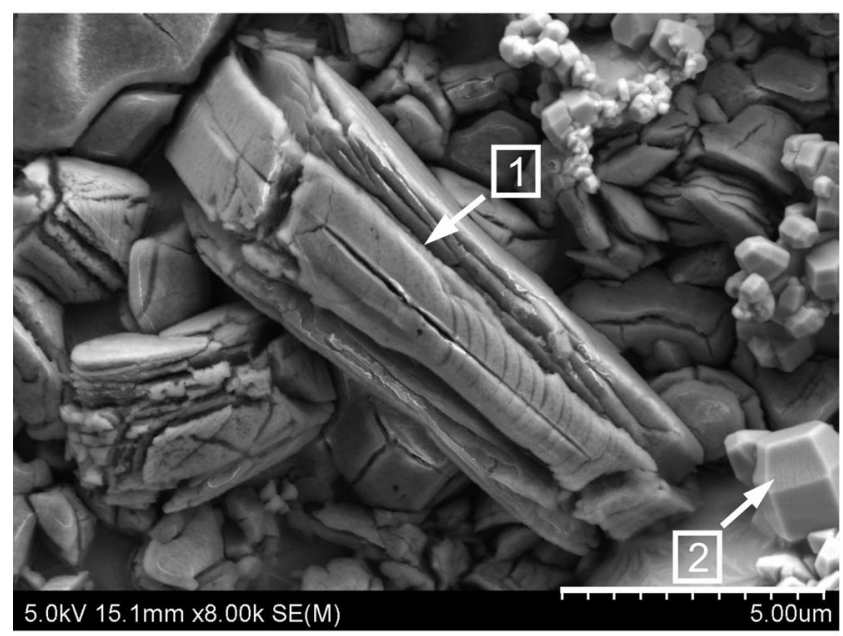

(c)

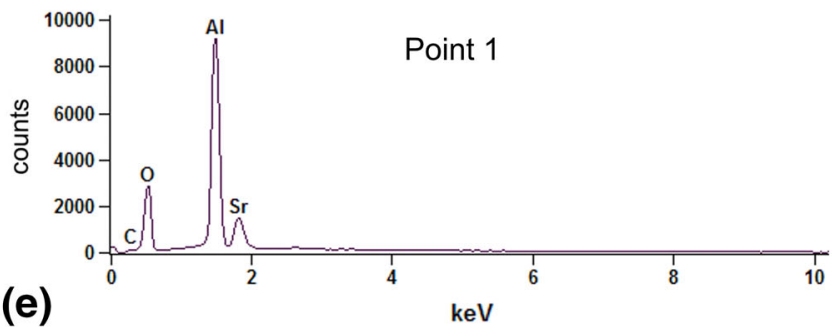

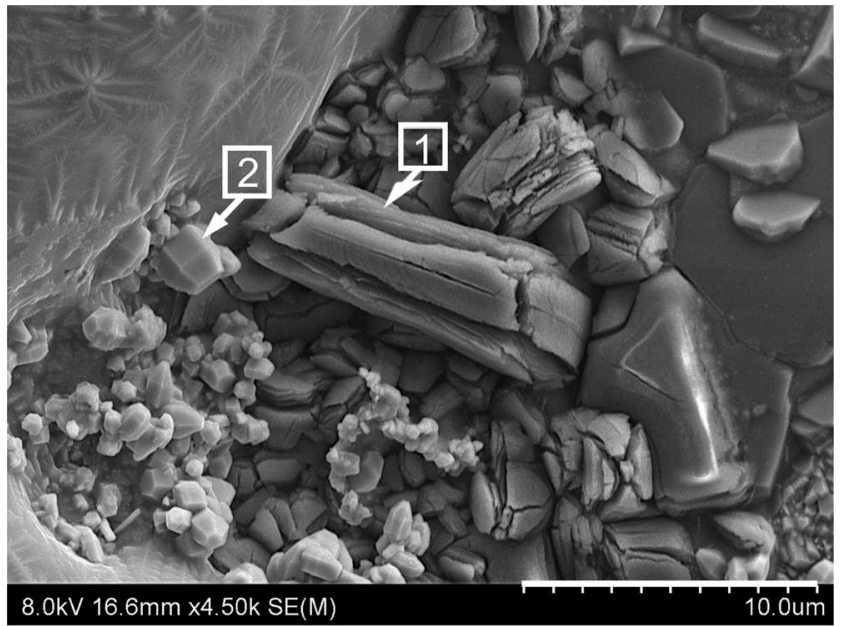

(b)

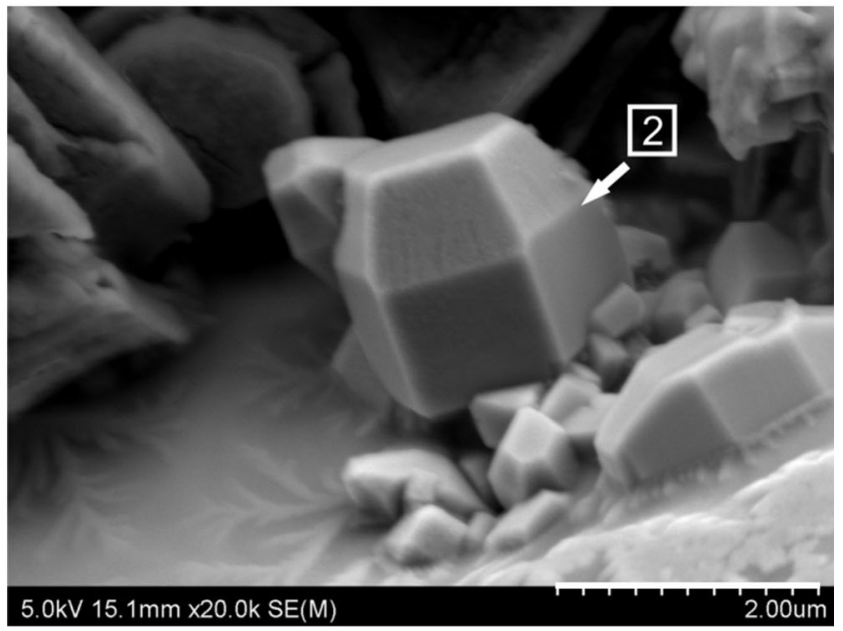

(d)

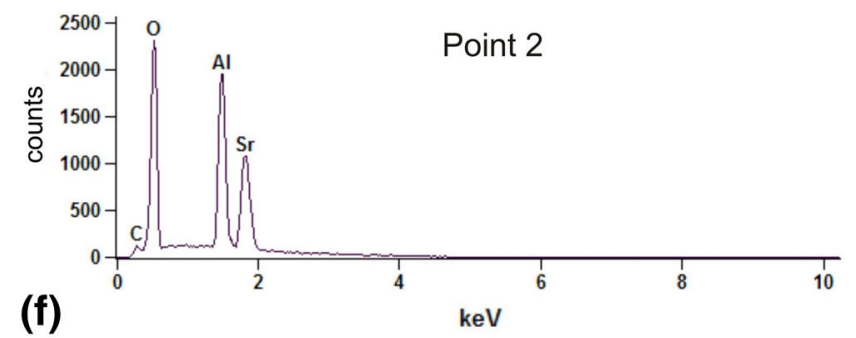

Fig. $7 \mathrm{SEM} / \mathrm{EDS}$ analysis of selected precipitates found in opened $\mathrm{AlSr} 10 / \mathrm{C}_{\text {glc }}$ interface $\left(800{ }^{\circ} \mathrm{C}, \mathrm{SD} / \mathrm{cp}+\mathrm{ds}, 120 \mathrm{~min}\right)$ : (a-d) SEM images (note that images $\mathrm{c}$ and $\mathrm{d}$ are open-down, compared to images a and b); (e, f) EDS analysis of regions marked by (1) and (2)

analysis of cuboidal precipitates (Fig. 7e) shows the presence of mainly $\mathrm{Al}, \mathrm{O}$, and $\mathrm{C}$, while that of the regular crystals (Fig. 7f) discloses Al, Sr, and O. It is worth to note that oxygen was not an alloying addition for the tested alloy. Therefore, we suggest that the regular crystals on the drop surface present $\mathrm{Al}_{4} \mathrm{Sr}$ phase, formed during solidification of residual AlSr10 drop.

The detailed surface characterization of the "snowflakes" region shown in Fig. 8(a) was made by AES analysis which enables the analysis of chemical composition of a few atomic layers. The results evidence the presence of the oxidized aluminum in points $\mathrm{P} 1$ and P2 (Fig. 8b), which was also detectable by EDS characterization presented in Fig. 7. The detailed analysis of the spectrum taken in point P2 (Fig. 8c) reveals the increased content of strontium in comparison to the other analyzed points and suggests it segregation at the interface.

Figure 9 shows the STEM images of the interface fashioned in the $800{ }^{\circ} \mathrm{C}$ test between the AlSr10 alloy drop and glass-like carbon substrate. The presence of a new phase reactively formed at the interface in the form of a layer was noticed by means of SE mode (Fig. 9a) as well as in bright field mode (Fig. 9b). This layer is discontinuous and exhibits strongly porous structure (Fig. 8c and d). It is composed of numerous 


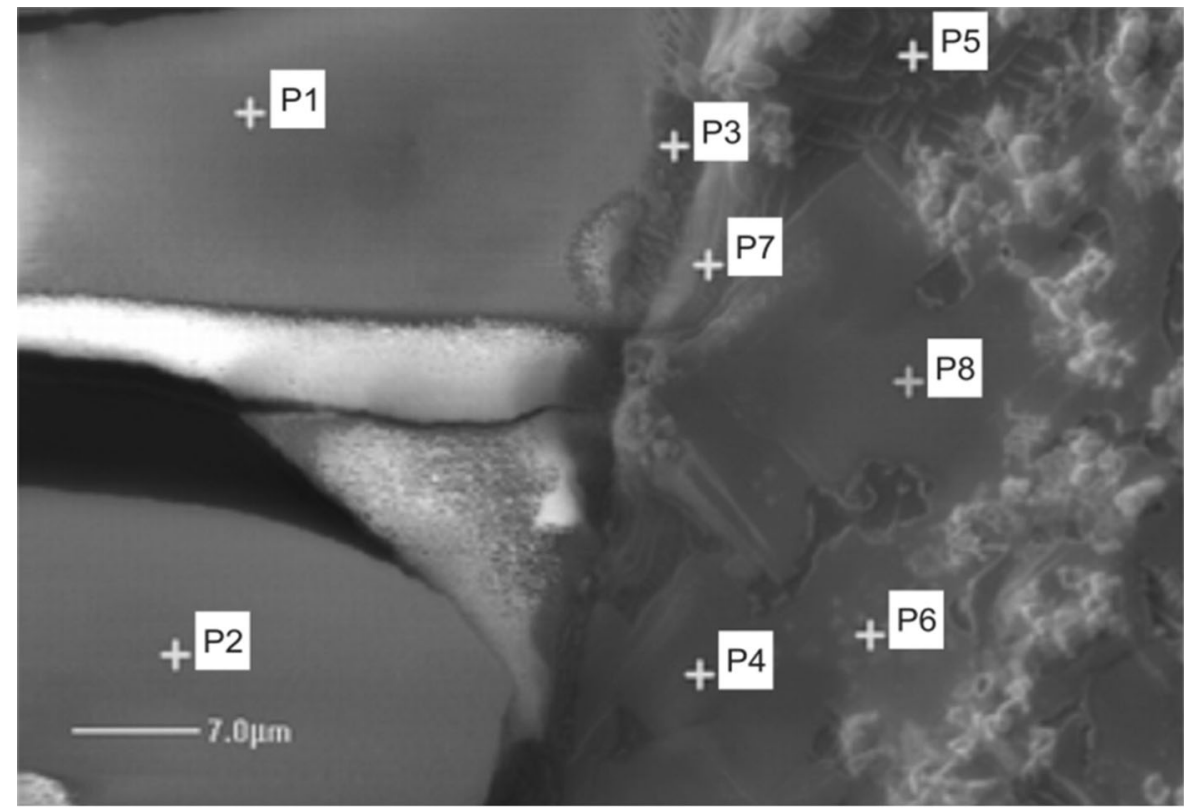

(a)

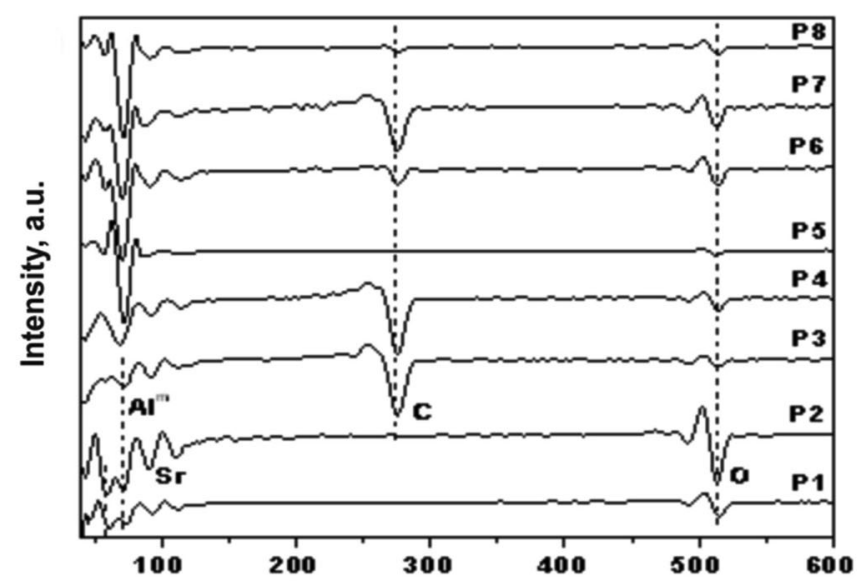

(b)

Kinetic energy, eV

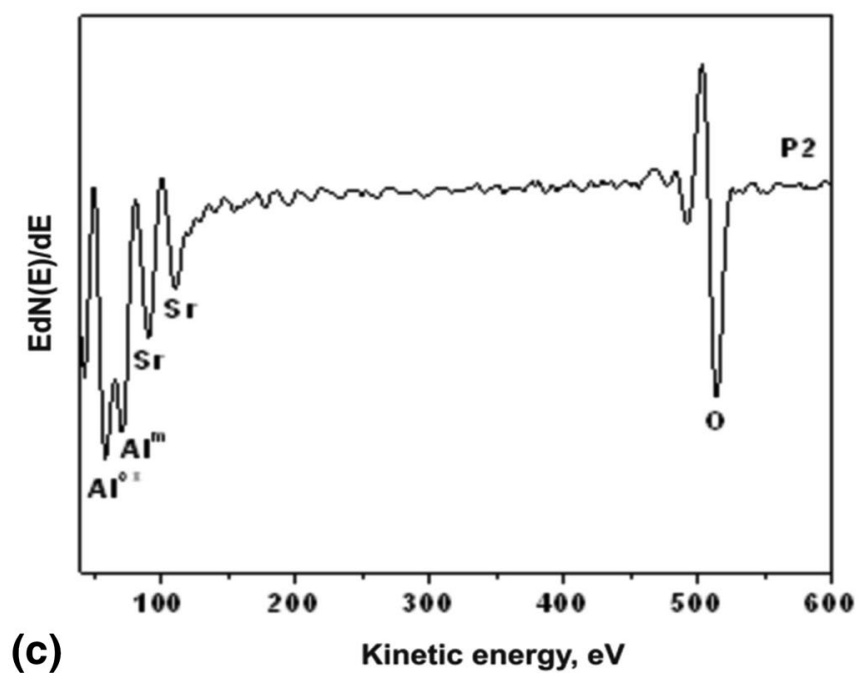

Fig. 8 The results of Auger electron spectrometry analysis of the in situ opened interface of the AlSr10/C $\mathrm{C}_{\text {glc }}$ couple after wettability test $\left(800^{\circ} \mathrm{C}, \mathrm{SD} / \mathrm{cp}+\mathrm{ds}, 120 \mathrm{~min}\right)$ : (a) general view with areas subjected to analysis; (b) spectra originated to points P1-P8; (c) detailed spectrum originated to point $\mathrm{P} 2$ 


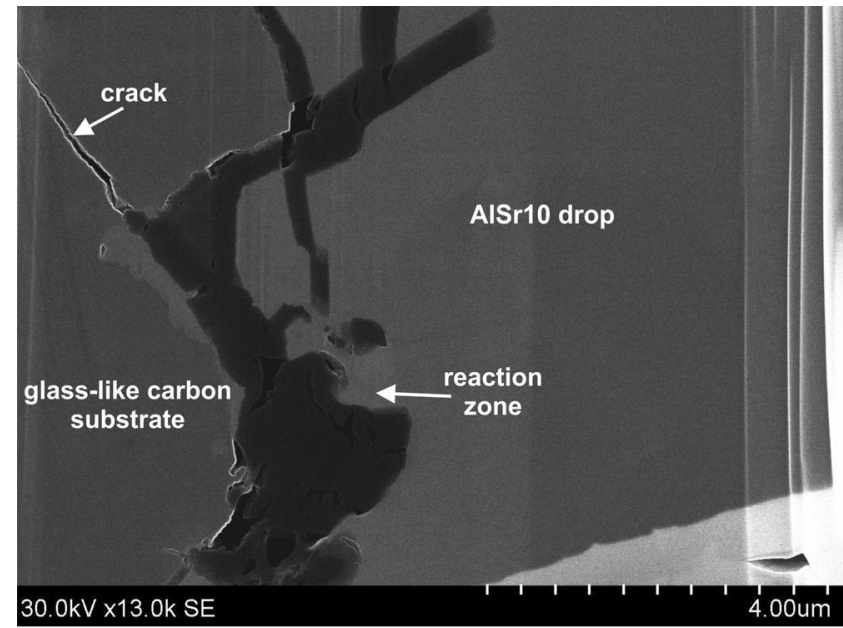

(a)

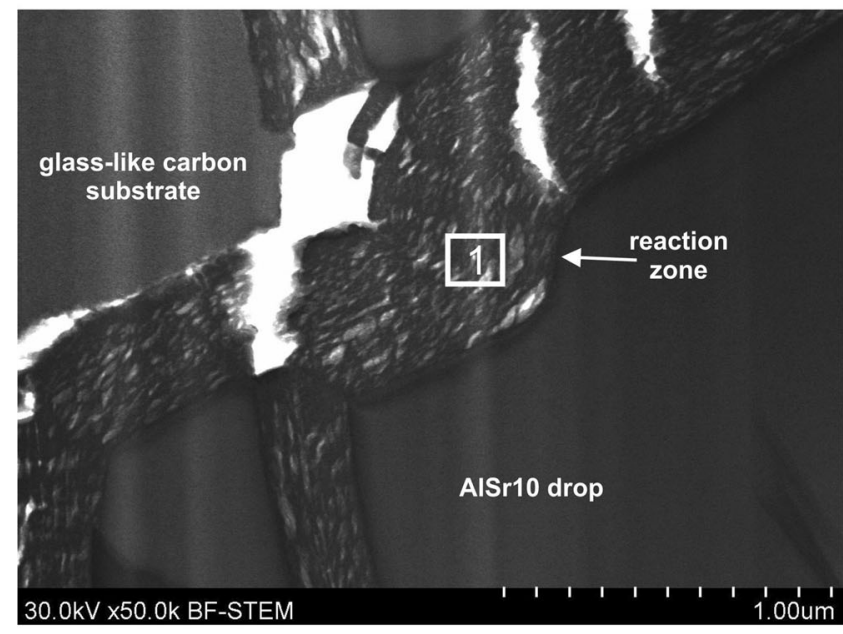

(c)

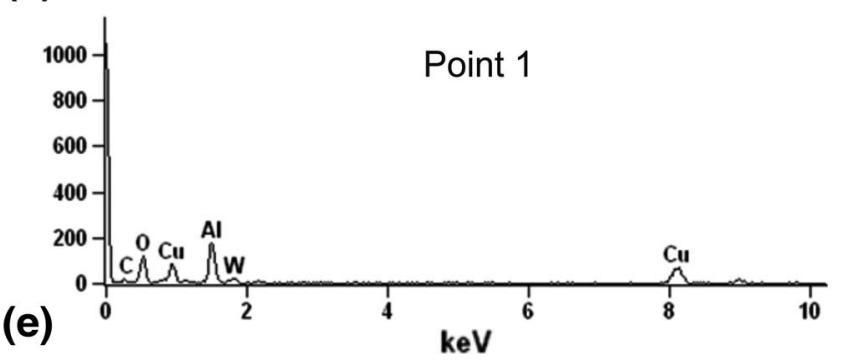

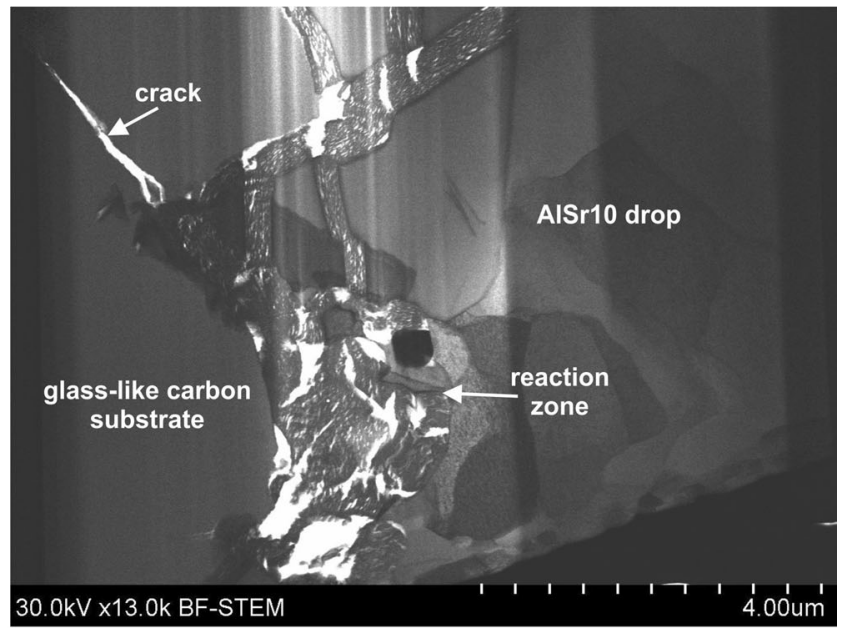

(b)

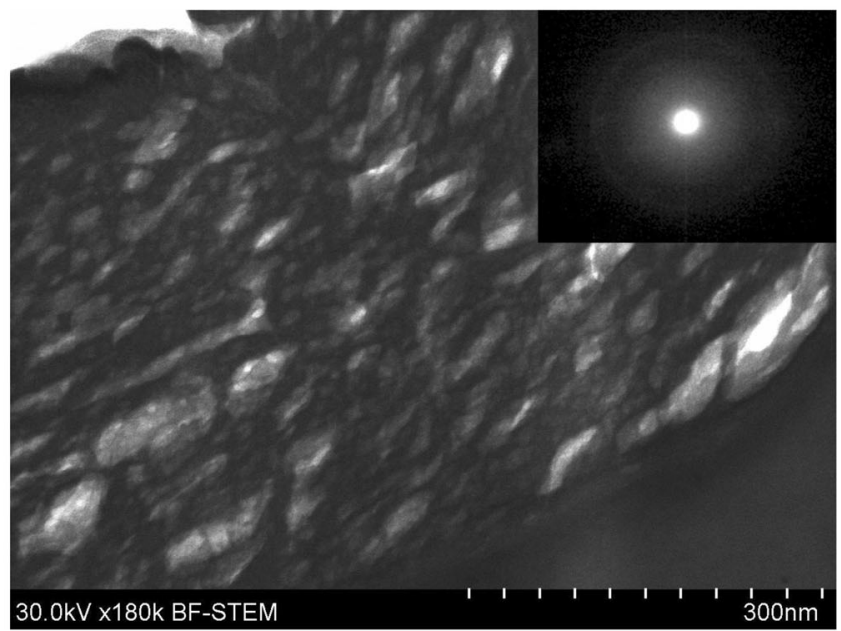

(d)

Fig. 9 STEM analysis of the cross-sectioned AlSr10/C $\mathrm{C}_{\text {glc }}$ sample $\left(800{ }^{\circ} \mathrm{C}, \mathrm{SD} / \mathrm{cp}+\mathrm{ds}, 120 \mathrm{~min}\right)$ : (a) general view in $\mathrm{SE}$ mode, (b-d) bright field mode, (e) EDS analysis of the structure carried out in the point 1 marked in Fig. 9(c)

precipitates that were found along the whole interface. In some areas of the substrate near the interface, the cracks are formed (white arrows in Fig. 9a and b). Selected area electron diffraction pattern taken from porous reaction product region indicates amorphous structure (inset in Fig. 9d). The EDS analysis of this region (Fig. 9e) reveals mainly aluminum and oxygen. The presence of $\mathrm{Cu}$ and $\mathrm{W}$ was caused by the sample preparation with FIB equipment.

It should be highlighted that despite the fact that STEM studies did not evidence the presence of structures characteristic for $\mathrm{Al}_{4} \mathrm{C}_{3}$ [e.g., reported in (Ref 5-8, 10, 36, 38)], its formation under conditions of wettability studies cannot be excluded because of a large amount of precipitates rich in $\mathrm{Al}$ and $\mathrm{O}$ were noted in the examined couple. The problems with $\mathrm{Al}_{4} \mathrm{C}_{3}$ identification, particularly when its amount is low, can be explained by high reactivity of $\mathrm{Al}_{4} \mathrm{C}_{3}$ with moisture from the air resulting in $\mathrm{Al}_{4} \mathrm{C}_{3} \rightarrow \mathrm{Al}(\mathrm{OH})_{3}$ transformation:

$$
\mathrm{Al}_{4} \mathrm{C}_{3}+12 \mathrm{H}_{2} \mathrm{O}=4 \mathrm{Al}(\mathrm{OH})_{3}+3 \mathrm{CH}_{4(\text { gas })}
$$

From the EDS analysis, one may suggest that the phase rich in $\mathrm{Al}$ and $\mathrm{O}$ corresponds to $\mathrm{Al}(\mathrm{OH})_{3}$ formed due to the decomposition of $\mathrm{Al}_{4} \mathrm{C}_{3}$ by water. Moreover, the reaction (1) is accompanied with the formation of gaseous reaction product 


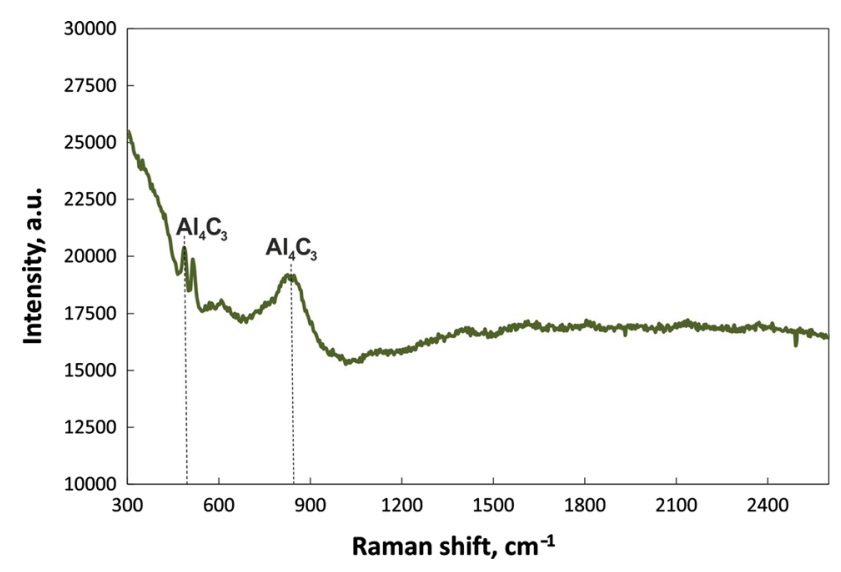

Fig. 10 Raman spectrum at $472 \mathrm{~nm}$ taken from the surface of AlSr10/C $\mathrm{Clc}_{\mathrm{glc}}$ sample as marked in Fig. 4

$\mathrm{CH}_{4}$ that in turn contributes to the development of structural discontinuities (cracks and voids) as indicated by STEM analysis (Fig. 9a-d, respectively). The Raman spectroscopy analysis of the drop/substrate interface (Fig. 10) confirms the above explanation since two strong peaks recorded at 490 and $855 \mathrm{~cm}^{-1}$ are typical for $\mathrm{Al}_{4} \mathrm{C}_{3}$.

Additional confirmation for the possibility to form $\mathrm{Al}_{4} \mathrm{C}_{3}$ at the AlSr10/C interface during SD tests was found from thermodynamic analysis. Both $\mathrm{Al}$ and $\mathrm{Sr}$ are carbide-forming elements and thus two reactions were taken into consideration:

$$
\frac{4}{3}[\mathrm{Al}]+\mathrm{C}=\frac{1}{3} \mathrm{Al}_{4} \mathrm{C}_{3} \quad \Delta G_{\mathrm{Al}_{4} \mathrm{C}_{3}}^{\mathrm{f}}=\Delta G_{\mathrm{Al}_{4} \mathrm{C}_{3}}^{0}+\frac{1}{3} R T \ln \frac{a_{\mathrm{Al}_{4} \mathrm{C}_{3}}}{\left(a_{\mathrm{Al}}\right)^{4}}
$$

$$
\frac{1}{2}[\mathrm{Sr}]+\mathrm{C}=\frac{1}{2} \mathrm{SrC}_{2} \quad \Delta G_{\mathrm{SrC}_{2}}^{\mathrm{f}}=\Delta G_{\mathrm{SrC}_{2}}^{0}+\frac{1}{2} R T \ln \frac{a_{\mathrm{SrC}_{2}}}{a_{\mathrm{Sr}}},
$$

where $\Delta G^{0}$ refers to the standard free energy of carbide formation per mole of carbon, $a$ is activity of $\mathrm{Al}$ or $\mathrm{Sr}$,

$R$ is the universal gas constant, and $T$ is the temperature at which the reaction takes place.

The "Reaction equation" module of thermo-chemical software and database of HSC Chemistry 6 were applied for calculation of the standard free energy of the formation of $\mathrm{Al}_{4} \mathrm{C}_{3}$ and $\mathrm{SrC}_{2}$. For both carbides, it is negative showing comparable values of $\Delta G_{\mathrm{Al}_{4} \mathrm{C}_{3}}^{0}=-54.182\left[\frac{\mathrm{kJ}}{\mathrm{mol}_{\mathrm{C}}}\right]$ and $\Delta G_{\mathrm{SrC}_{2}}^{0}=-48.616\left[\frac{\mathrm{kJ}}{\mathrm{mol}_{\mathrm{C}}}\right]$. Consequently, one may conclude that both carbides can be formed. On the other hand, the activity of Sr in the AlSr10 alloy at $800{ }^{\circ} \mathrm{C}$ is very low $\left(1.9 \times 10^{-4}\right)$. Therefore, we suggest that under conditions of the SD test used in this study, the formation of $\mathrm{SrC}_{2}$ by the reaction (3) in the $\mathrm{AlSr} 10 / \mathrm{C}$ system is impossible.

Moreover, thermodynamic evaluation for the following possible interfacial reaction

$$
2 \mathrm{Al}_{4} \mathrm{C}_{3(\mathrm{~s})}+3 \mathrm{Sr}_{(1)}=3 \mathrm{SrC}_{2(\mathrm{~s})}+8 \mathrm{Al}_{(1)}
$$

shows positive value of $\Delta G^{0}=33.399 \mathrm{~kJ}$, thus also suggesting that the formation of $\mathrm{SrC}_{2}$ is not thermodynamically favorable.
The above thermodynamic considerations approve the possibility for the formation of $\mathrm{Al}_{4} \mathrm{C}_{3}$ and are in agreement with the results of Raman spectroscopy characterization and TEM/EDS analysis. On the other hand, structural observations do not show clear evidence for the formation of continuous layer of $\mathrm{Al}_{4} \mathrm{C}_{3}$ in the triple line region. Therefore, we may conclude that in the Al-Sr/C system, the contribution of $\mathrm{Al}_{4} \mathrm{C}_{3}$ to the reactive wetting mechanism through the formation of wettable reaction product layer is less obvious and the main reason of wettability improvement by alloying Al with 10 wt.\% $\mathrm{Sr}$ is related with effective lowering of surface tension of the $\mathrm{Al}-\mathrm{Sr}$ alloy and adsorption of $\mathrm{Sr}$ at the interface.

\section{Summary}

The SD tests performed at industrially important temperatures of $700-800{ }^{\circ} \mathrm{C}$ under vacuum using capillary purification procedure combined with non-contact heating of a couple of materials show that alloying $\mathrm{Al}$ with $10 \mathrm{wt} \% \mathrm{Sr}$ improves wetting in the $\mathrm{Al} / \mathrm{C}$ system.

Scanning and transmission electron microscopy combined with energy-dispersive x-ray spectroscopy and Auger electron spectrometry as well as scanning probe microscopy combined with Raman spectroscopy of the interface, in situ exposed directly in vacuum chamber and thus less affected by cooling history, suggest that the dominant role in the observed wettability improvement is related with significant lowering of the surface tension of liquid metal and adsorption of $\mathrm{Sr}$ at the interface.

\section{Acknowledgments}

The work has been done under the project "3D textile reinforced aluminum matrix composites for complex loading situations in light-weight automobile and machine parts," financed by the Ministry of Science and Higher Education in Poland (Project No. 106/N-DFG/2008/0 and No. 796/N-DFG/2010/0).

\section{Open Access}

This article is distributed under the terms of the Creative Commons Attribution 4.0 International License (http://creativecommons. org/licenses/by/4.0/), which permits unrestricted use, distribution, and reproduction in any medium, provided you give appropriate credit to the original author(s) and the source, provide a link to the Creative Commons license, and indicate if changes were made.

\section{References}

1. M.G. Nicholas, D.A. Mortimer, Proceedings of the International Conference on Carbon Fibers, their Composite and Appliction, 1971, London, p 19/1-19/3

2. N. Eustathopoulos, J.C. Joud, P. Desre, and J.M. Hicter, The Wetting of Carbon by Aluminium and Aluminum Alloy, J. Mater. Sci., 1974, 9, p 1233-1248

3. A.A. Zabolockij, ed. by J.N. Fridlander, V.I. Kostikov, Proc. MICC 90, 1990, (Moscow), Elsevier Appl. Sci., p 337-340

4. P.J. Bunyan, S.H. Huo, Electromagnetic Enhancement of Wetting in the $\mathrm{Al}-\mathrm{Al}_{2} \mathrm{O}_{3}$ and Al-Graphite Systems, Chandra T, Dhingra AK, Ed., 
Proceedings of the International Conference on Advanced Composites'93, 1993, p 1009-1014

5. S. Kalogeropoulou, K. Landry, and N. Eustathopoulos, Wettability and Reactivity in the Aluminium/Carbon System, Mater. Sci. Forum, 1993, 126-128, p 683-686

6. K. Landry, S. Kalogeropoulou, N. Eustathopoulos, Y. Naidich, and V. Krasovsky, Characteristic Contact Angles in the Aluminium/Vitreous Carbon System, Scr. Mater., 1996, 34(6), p 841-846

7. N. Sobczak, Z. Gorny, M. Ksiazek, W. Radziwill, and P. Rohatgi, Interaction Between Porous Graphite Substrate and Liquid or SemiLiquid Aluminium Alloys Containing Titanium, Mater. Sci. Forum, 1996, 217-222(1), p 153-158

8. K. Landry, S. Kalogeropoulou, and N. Eustathopoulos, Wettability of Carbon by Aluminum and Aluminum Alloys, Mater. Sci. Eng., 1998, 254, p 99-111

9. N. Eustathopoulos, M.G. Nicholas, and B. Drevet, Wettability at High Temperatures, Pergamon, Amsterdam, 1999, p 420

10. N. Sobczak, Effect of Alloying Elements on Wettability and Interfaces in Aluminum-Carbon System, Proceedings of EMRS Conference Light Alloys and Composite, Zakopane, Poland, 1999, p 341-350

11. N. Sobczak, Improvement of Wetting and Bonding of Dissimilar Materials, in Interfacial Science in Ceramic Joining, NATO ASI, Series, 3. High Technology, Vol 58, A. Bellosi, T. Kosmac, and A.P. Tomsia, Ed., Kluwer Academic Publishers, Dordrecht, 1998, p 27-42

12. R. Asthana and N. Sobczak, Wettability, Spreading, and Interfacial Phenomena in High-Temperature Coatings, JOM-e, 2000, 52(1), p 1-19

13. D.A. Weirauch, W.M. Balaba, and A.J. Perotta, Kinetics of the Reactive Spreading of Molten Aluminum on Ceramic Surfaces, J. Mater. Res., 1995, 10, p 640-650

14. S. Seal, T.L. Barr, N. Sobczak, and S.J. Kerber, Microscopy and Electron Spectroscopic Study of the Interfacial Chemistry in Al-Ti Alloy/Graphite Systems, J. Mater. Sci., 1998, 33(16), p 4147-4158

15. S. Seal, T. Warwick, N. Sobczak, and J. Morgiel, A Scanning Photoemission Microscope (SPEM) to Study the Interface Chemistry of AlTi/C System, J. Mater. Sci. Lett., 2000, 19(2), p 123-126

16. N. Sobczak, J. Sobczak, S. Seal, and J. Morgiel, TEM Examination of the Effect of Titanium on the $\mathrm{Al} / \mathrm{C}$ Interface Structure, Mater. Chem. Phys., 2003, 81(2), p 319-322

17. P. Baumli, J. Sytchev, and G. Kaptay, Perfect Wettability of Carbon by Liquid Aluminum Achieved by a Multifunctional Flux, J. Mater. Sci. 2010, 45(19), p 5177-5190

18. E. Candan, Effect of Alloying Elements to Aluminium on the Wettability of Al/SiC System, Turk. J. Eng. Environ. Sci., 2002, 26, p 1-5

19. A. Alonso, A. Pamies, J. Narciso, C. Garcia-Cordovilla, and E. Louis, Evaluation of the Wettability of Liquid Aluminum with Ceramic Particulates ( $\mathrm{SiC}, \mathrm{TiC}, \mathrm{Al}_{2} \mathrm{O}_{3}$ ) by Means of Pressure Infiltration, Metall. Trans. A, 1993, 24A, p 1423-1432

20. D. Emadi, J.E. Gruzleski, and J.M. Toguri, The Effect of $\mathrm{Na}$ and $\mathrm{Sr}$ Modification on Surface Tension and Volumetric Shrinkage of A356 Alloy and Their Influence on Porosity Formation, Metall. Trans. B, 1993, 24B, p 1055-1063
21. J.P. Anson, R.A.L. Drew, and J.E. Gruzleski, The Surface Tension of Molten Aluminum and Al-Si-Mg Alloy under Vacuum and Hydrogen Atmospheres, Metall. Trans. B, 1998, 30B, p 1027-1032

22. G. Lang, Casting Properties and Surface Tension of Aluminum and Binary Aluminum Alloys Part III: Surface Tension, Aluminum, 1973, 49(3), p 231-238

23. G. Lang, The Influence of Alloying Elements on the Surface Tension of Liquid Super Purity Aluminum, Aluminum, 1974, 50(11), p 731-734

24. E. Ricci, D. Giuranno, and N. Sobczak, Further Development of Testing Procedures for High Temperature Surface Tension Measurements, JMEPEG, 2013, 22(11), p 3381-3388

25. B.J. Keene, Review of Data for the Surface Tension of Pure Metals, Int. Mater. Rev., 1993, 38(4), p 157-192

26. J.M. Molina, R. Voytovych, E. Louis, and N. Eustathopoulos, The Surface Tension of Liquid Aluminium in High Vacuum: The Role of Surface Condition, Int. J. Adhes. Adhes., 2007, 27, p 394-401

27. A.M. Korol'kov, Effect of Added Elements on the Surface Tension of $99.99 \%$ aluminum at 700 to $740{ }^{\circ} \mathrm{C}$ in Argon, Otdelenie Teknicheskik Nauk, 1956, 2, p 35-42

28. C.R.J. Loper, American Foundrymen Society Transactions, 1992, 147, p 533-538

29. I. Egry, J. Brillo, D. Holland-Moritz, and Yu Plevachuk, The Surface Tension of Liquid Aluminium-Based Alloys, Mat. Sci. Eng. A, 2008, 495, p 14-18

30. M. Bahraini, J.M. Molina, M. Kida, L. Weber, J. Narciso, and A. Mortensen, Measuring and Tailoring Capillary Forces During Liquid Metal Infiltration, Curr. Opin. Solid State Mater., 2005, 9, p 196-201

31. J.M. Molina, A. Rodriguez-Guerrero, M. Bahraini, L. Weber, J. Narciso, F. Rodriguez-Reinoso, E. Louis, and A. Mortensen, Infiltration of Graphite Preforms with Al-Si Eutectic Alloy and Mercury, Scr. Mater., 2007, 56, p 991-994

32. A. Rodriguez-Guerrero, S.A. Sanchez, J. Narciso, E. Louis, and F. Rodriguez-Reinoso, Pressure Infiltration of Al-12 wt.\% Si-X $(\mathrm{X}=\mathrm{Cu}$, $\mathrm{Ti}, \mathrm{Mg}$ ) Alloys into Graphite Particle Preforms, Acta Mater., 2006, 54, p 1821-1831

33. N. Eustathopoulos, N. Sobczak, A. Passerone, and K. Nogi, Measurement of Contact Angle and Work of Adhesion at High Temperature, $J$. Mater. Sci., 2005, 40(9-10), p 2271-2280

34. N. Sobczak, M. Singh, and R. Asthana, High-Temperature Wettability Measurements in Metal/Ceramic Systems-Some Methodological Issues, Curr. Opin. Solid State Mater. Sci., 2005, 9(4), p 241-253

35. N. Sobczak, R. Nowak, W. Radziwill, J. Budzioch, and A. Glenz, Experimental Complex for Investigations of High Temperature Capillarity Phenomena, Mater. Sci. Eng., 2008, A495(1), p 43-49

36. N. Sobczak, R. Asthana, W. Radziwill, R. Nowak, and A. Kudyba, The Role of Aluminium Oxidation in the Wetting-Bonding Relationship of Al/Oxide Couples, Archiv. Metall. Mater., 2007, 52(1), p 55-65

37. ASTRA Reference Book, IENI, Report, 2007

38. J. Sobczak, N. Sobczak, R. Asthana, A. Wojciechowski, K. Pietrzak, and D. Rudnik, Atlas of Cast Metal-Matrix Composites, Motor Transport Institute, Foundry Research Institute, Warsaw, 2007 